\title{
Peningkatan Keterampilan Menulis Deskripsi Melalui Metode Problem Based Learning di Kelas IV SDN 3 Selajambe
}

\author{
Junaedi Nugraha, Zulela, M.S, Nurhattati Fuad \\ Universitas Negeri Jakarta \\ zunnoegraha19@gmail.com
}

\section{Sejarah Artikel}

diterima 28 Oktober 2020 disetujui 20 November 2020 diterbitkan 1 Desember 2020

\begin{abstract}
The aim of the research is to improve descriptive writing skills through using problem-based learning at fourth grade of SDN 3 Selajambe Kuningan Regency. The research is a classroom action research using Kemmis and Mc. Taggart Design. The study was conducted in two cycles where each cycle consisted of four stages, namely planning, acting. Observe and reflect. Data collection is done through descriptive writing tests, observation sheets and documentation. The results showed an increase in descriptive writing skills of fourth grade students of SDN 3 Selajambe Kuningan District through using problem-based learning methods. The increase can be seen from the product average and learning completeness which before using the action is 61.4 with a percentage of completeness of $36 \%$. The increase in the first cycle increased to 69.6 increased by $24 \%$ with the percentage of completeness reaching $60 \%$, and in the second cycle increased to 75.6 increased by $28 \%$ with the percentage completeness was $88 \%$. In conclusion, learning through using problem-based learning can improve the descriptive writing skills of students in Indonesian subjects Indonesia subject at fourth grade of SDN 3 Selajambe Kuningan Regency.
\end{abstract}

Keyword: writing skill, scientific approach, problem based learning method

\begin{abstract}
Abstrak
Penelitian ini bertujuan untuk meningkatkan keterampilan menulis deskripsi melalui metode problem based learning pada siswa kelas IV SDN 3 Selajambe Kabupaten Kuningan. Penelitian ini merupakan penelitian tindakan kelas dengan menggunakan model Kemmis dan Mc Taggart yang dilakukan dalam dua siklus. Setiap siklus terdiri dari empat tahapan yaitu: Perencanaan, Tindakan, Observasi dan Refleksi. Pengumpulan data dilakukankan menggunakan instrumen tes menulis deskripsi, lembar pemantau tindakan dan dokumentasi. Hasil penelitian menunjukan adanya peningkatan keterampilan menulis deskripsi pada siswa kelas IV SDN 3 Selajambe Kabupaten Kuningan melalui metode problem based learning. Peningkatan ini dilihat dari nilai rata-rata produk dan ketuntasan belajar yang sebelumnya sebesar 61,4 dengan persentase ketuntasan hanya $36 \%$. Peningkatan pada siklus I sebesar 69,6 dengan persentase ketuntasan belajar $60 \%$ meningkat $24 \%$, dan pada siklus II meningkat menjadi 75,6 dengan persentase ketuntasan mencapai $88 \%$ meningkat sebesar $28 \%$. Dengan demikian pembelajaran melalui metode problem based learning dapat meningkatkan keterempilan menulis deskripsi pada pelajaran Bahasa Indonesia kelas IV SDN 3 Selajambe Kabupaten Kuningan.
\end{abstract}

Kata kunci : keterampilan menulis, metode problem based learning 


\section{PENDAHULUAN}

Untuk menghasilkan manusia yang berkualitas diperlukan pembelajaran yang berkualitas pula. Melalui pembelajaran yang berkualitas, peserta didik dibimbing untuk dapat mengembangkan potensi yang dimiliki dengan melakukan berbagai kegiatan secara aktif. Melalui pembelajaran aktif, peserta didik akan beriteraksi dengan peserta didik lainnya melalui konteks, metode, dan media yang terintegrasi sehingga pembelajaran akan bermakna.

Salah satu mata pelajaran yang penting diberikan dalam pembelajaran di sekolah khususnya di sekolah dasar adalah Bahasa Indonesia. Hal ini mengingat, Bahasa Indonesia merupakan bahasa nasional yang digunakan bangsa Indonesia. Bahasa Indonesia merupakan bahasa komunikasi yang digunakan pada semua pembelajaran. Bahasa Indonesia merupakan bahasa pengantar dalam semua pembelajaran.

Mengingat pentingnya Bahasa Indonesia, maka kemampuan berbahasa harus dibina sejak dini agar menjadi bekal yang sangat berharga bagi anak dalam memasuki jenjang pendidikan selanjutnya. Untuk itu, pembelajaran Bahasa Indonesia khususnya di sekolah dasar harus diberikan secara optimal agar peserta didik memiliki kemampuan berbahasa yang baik dan benar.

Terdapat empat aspek keterampilan berbahasa yang harus dikuasai peserta didik, yakni keterampilan menyimak, berbicara, membaca, dan menulis. Keempat keterampilan tersebut memiliki hubungan satu sama lain. Apabila salah satu keterampilan berbahasa tersebut tidak dapat dikuasai peserta didik, maka proses berbahasa yang dimiliki tidak akan berjalan dengan baik.

Salah satu keterampilan yang harus dikuasai peserta didik dalam Bahasa Indonesia adalah keterampilan menulis. Menulis merupakan keterampilan berbahasa yang terakhir setelah keterampilan membaca. Keterampilan menulis sangat penting untuk dikuasai peserta didik karena dengan menulis peserta didik dapat mengekspresikan ide, pikiran, dan gagasannya melalui tulisan. Salah satu keterampilan menulis adalah menulis deskripsi. Menulis pada dasarnya adalah proses untuk mengemukakan ide dan gagasan dalam bahasa tulis (Abidin, 2012), menulis merupakan suatu bentuk ekspresi ide, dan perasaan yang dilakukan secara tertulis (Jamaris dalam Juldianty, 2012). Pendapat lain menyebutkan bahwa menulis adalah sebuah aktivitas yang kompleks, bukan hanya sekedar menggunakan kalimat- kalimat tetapi lebih dari itu,menulis adalah proses menuangkan pikiran dan menyampaikan kepada khalayak (Kartono dalam Ansyoriah, 2017).

Selanjutnya dinyatakan bahwa menulis merupakan kegiatan menuangkan pikiran, gagasan, dan perasaan seseorang yang diungkapkan dalam bentuk bahasa tulis (Muhtadi dalam Laksitarini,2016). Sejalan dengan pendapat tersebut bahwa menulis adalah kegiatan menyampaikan pesan (komunikasi) dengan menggunakan bahasa tulis sebagai alat atau medianya (Suparno dan M.Yunus dalam Dalman, 2016).

Berdasarkan beberapa konsep yang dikemukakan di atas maka dapat disimpulkan bahwa keterampilan menulis ialah kesanggupan atau 
kecakapan seseorang dalam menuangkan ide, gagasan, atau suatu pemikiran yang dituangkan melalui bahasa tulis sebagai media dalam menyampaikan pesan atau informasi untuk dapat di pahami oleh orang lain / pembaca. Deskripsi berasal dari kata "describe" yang berarti menulis tentang, atau membeberkan hal. Dalam bidang karang mengarang, deskripsi dimaksudkan sebagai suatu karangan yang digunakan penulis untuk memindahkan kesan- kesannya, memindahkan hasil pengamatan dan perasaannya, dan disajikan kepada para pembaca. Dalam hal ini deskripsi adalah bentuk tulisan yang bertujuan memperluas pengetahuan dan pengalaman pembaca dengan jalan melukiskan hakikat objek yang sebenarnya (Finoza dalam Dalman, 2016). Ahli lain seperti (Semi,2007) berpendapat bahwa deskripsi ialah tulisan yang tujuannya untuk memberikan rincian atau detail tentang objek sehingga dapat memberi pengaruh pada emosi dan menciptakan imajinasi pembaca bagaikan melihat, mendengar, atau merasakan langsung apa yang disampaikan penulis. Pendapat lain seperti (Slamet dalam Supardi,2015) mengungkapkan bahwa deskripsi (pemerian) adalah wacana yang melukiskan atau menggambarkan sesuatu berdasarkan kesan- kesan dari pengamatan, pengalaman, dan perasaan penulisnya. Sedangkan menurut (Marahimin dalam godvany,2017) bahwa deskripsi adalah pemaparan atau penggambaran dengan kata- kata suatu benda, tempat, suasana atau kejadian.

Berdasarkan dari beberapa konsep yang di paparkan di atas maka dapat disimpulkan bahwa menulis deskripsi adalah tulisan atau karangan yang melukiskan suatu kejadian atau peristiwa secara jelas seolah- olah pembaca dapat merasakan dan mengalamai secara langsung apa yang diceritakan oleh penulis.

Dengan demikian, keterampilan menulis deskripsi di sini ialah kesanggupan atau kecakapan siswa dalam menuangkan gagasan, ide ataupun suatu pemikiran melalui sebuah media tulis berdasarkan dari pengalaman yang mereka alami dan ditulis secara detail sehingga menimbulkan emosi kepada para pembaca seolah-olah pembaca ikut melihat, mendengar, dan merasakan langsung apa yang penulis ceritakan.

Namun kenyataan di lapangan, keterampilan menulis merupakan salah satu permasalahan yang dihadapi peserta didik. Permasalahan yang dihadapi adalah ketidakmampuan dalam menemukan apa yang hendak ditulis, apa topiknya dan bagaimana memulainya. Selain itu, kurangnya kemampuan dalam menuangkan ide atau gagasan secara sistematis dan logis. Hal tersebut nampak dari tulisan peserta didik yang tidak beraturan atau bahkan kalimat yang satu dengan yang lainnya tidak saling berhubungan. Peserta didik juga belum mampu menggunakan bahasa yang baik dan benar. Dapat dilihat pada tulisan peserta didik yang kurang sesuai dengan aturan-aturan ejaan dalam menulis (Pramita, 2017). Salah satu hasil penelitian mengemukakan bahwa 64\% siswa kelas 2 Bintang SDN Pandanwangi 1 belum mampu menulis deskripsi. Hal ini terjadi karena, siswa belum mengenal cara menulis deskripsi yang baik dan benar (Badawi, 2016). Hasil penelitian yang dilakukan di SD Negeri 1 Penarukan, ditemukan kendala-kendala yang terdapat dalam proses pembelajaran bahasa Indonesia terutama pada aspek 
menulis. Guru kelas IV mengungkapkan masih banyak siswa mengalami kesulitan dalam mengolah kata menjadi menjadi sebuah kalimat. Selain itu siswa sangat sulit menuangkan ide atau gagasangagasannya. Siswa juga belum mampu menempatkan penggunaan huruf kapital dan tanda titik. (Ni Kadek

Diana Sari,' I Made Suarjana, dan $\mathrm{Ni}$ Wayan Arin, 2016).

Rendahnya keterampilan menulis disebabkan oleh beberapa faktor baik internal maupun eksternal. Salah satu faktor eksternal adalah rendahnya peran guru dalam membimbing peserta didik agar terampil menulis. Pembelajaran menulis yang seharusnya membimbing peserta didik untuk berlatih mengemukakan gagasan masih belum dilakukan secara optimal. Selama peserta didik belajar menulis, ditemukan guru bersantai di ruang kelas bahkan meninggalkan kelas untuk melaksanakan kegiatan lain. Selain itu, kebiasaan guru yang tidak memberikan penilaian secara tepat keterampilan menulis peserta didik menjadikan peserta didik tidak termotivasi untuk menulis. Hasil tulisan peserta didik terkadang hanya dinilai dari banyaknya paragraf yang dihasilkan, kerapihan tulisan, dan faktor lain yang tidak esensial (Abidin, 2012).

Permasalahan pembelajaran menulis yang terjadi juga di Sekolah Dasar Negeri 3 Selajambe Kabupaten Kuningan. Kegiatan pembelajaran didominasi oleh guru. Dari sejak guru menerangkan tentang menulis, hingga memberikan tugas kepada peserta didik untuk menulis sesuai dengan tema atau judul yang telah ditentukan, tanpa bimbingan bagaimana menulis yang benar. Guru hanya memberikan perintah kepada peserta didik untuk membuat sebuah karangan tanpa memberikan perlakuan yang dapat menumbuhkan minat peserta didik dalam menulis. Ditemukan pula beberapa masalah, diantaranya peserta didik belum memiliki minat untuk menulis karangan; peserta didik hanya menulis seadanya pada saat guru menugasi peserta didik untuk menulis karangan; peserta didik kesulitan dalam menggali ide yang hendak ditulis; peserta didik kesulitan dalam menuangkan gagasan ke dalam bentuk karangan. Selain itu guru belum sepenuhnya menggunakan model pembelajaran yang bervariasi. Guru lebih banyak menggunakan metode pembelajaran ceramah ditambah dengan penugasan saja, selain tidak tumbuhnya minat dalam pembelajaran menulis, siswa kurang begitu memiliki bayangan terhadap gagasan yang hendak mereka tuangkan kedalam bentuk karangan.

Dari pengamatan tersebut dapat dikatakan bahwa pembelajaran menulis yang dilaksanakan di Sekolah Dasar Negeri 3 Selajambe Kabupaten Kuningan masih tergolong rendah, hal ini terlihat dari hasil menulis karangan peserta didik, diantaranya dalam pemilihan kata yang digunakan kurang sesuai, penggunaan tanda baca belum tepat, hubungan antar kalimat, kalimat sebelumnya dengan kalimat selanjutnya, serta keefektifan kalimat yang masih kurang antar paragraf.

Permasalahan yang dihadapi dalam mengembangkan keterampilan menulis di Sekolah Dasar menuntut guru untuk secara terus menerus meningkatkan kualitas pembelajaran Bahasa Indonesia. Guru dituntut untuk menggunakan berbagai strategi atau pendekatan atau metode pembelajaran yang mampu memberikan peluang kepada siswa untuk secara aktif mengembangkan 
potensi yang dimilikinya. Selain itu guru dituntut untuk menggunakan berbagai media yang mampu mempermudah siswa di dalam mempelajari materi pembelajaran.

Salah satu alternatif adalah metode pembelajaran berbasis masalah. Dalam kurikulum 2013, pembelajaran berbasis masalah merupakan salah satu model yang disarankan untuk dapat diterapkan oleh guru pada saat pembelajaran. Problem based learning merupakan salah satu model pembelajaran inovatif yang dapat memberikan kondisi belajar aktif kepada peserta didik (Ngalimun, dalam Kusrianti 2019).

Sejalan dengan pernyataan tersebut Problem Based Learning merupakan model pembelajaran yang melibatkan siswa dalam memecahkan masalah nyata. model ini menyebabkan motivasi dan rasa ingin tahu menjadi meningkat (Qodriah, Hartati, \& Karim, 2019). Metode PBL juga menjadi wadah bagi siswa untuk dapat mengembangkan cara berpikir kritis dan keterampilan berpikir yang lebih tinggi (Gunantara, dalam Suari 2018).

Berdasarkan dari beberapa teori yang telah di paparkan di atas maka dapat disimpulkan bahwa metode pembelajaran problem based learning adalah metode pembelajaran yang menjadikan dunia nyata sebagai konteks dari masalah yang akan di pelajari sebagai suatu pembelajaran yang dapat digunakan untuk dapat mengambangkan kemampuan dalam berpikir kritis sekaligus dalam pemecahan masalah yang sedang dipelajari.

Sumantri (Atmaningsih, 2019) mengungkapkan adapun langkahlangkah model PBL diantaranya: 1) Orientasi siswa pada masalah: Guru menjelaskan tujuan pembelajaran, menjelaskan alat bahan yang dibutuhkan, mengajukan fenomena atau demonstrasi atau cerita untuk memunculkan masalah, memotivasi siswa untuk terlibat dalam pemecahan masalah yang dipilih, 2) Mengorganisasikan siswa untuk belajar: Guru membantu siswa untuk mendefinisikan dan mengorganisasikan tugas belajar yang berhubungan dengan masalah tersebut, 3) Membimbing penyelidikan individual maupun kelompok: Guru mendorong untuk mengumpulkan informasi yang sesuai, melaksanakan eksperimen untuk medapatkan penjelasan dan pemecahan masalah, 4) Mengembangkan dan menyajikan hasil karya: Guru membantu siswa merencanakan dan menyiapkan karya yang sesuai seperti laporan, video, dan model serta membantu mereka untuk berbagi tugas dengan temannya, dan 5) Menganalisis dan mengevaluasi proses pemecahan masalah: Guru membantu siswa untuk melaksanakan refleksi atau evaluasi terhadap penyelidikan mereka dan prosesproses yang mereka gunakan (Karim et al., 2020).Sehingga dengan menggunakan pendekatan saintifik dengan metode problem based learning diharapkan dapat mengaktifkan siswa dalam proses pembelajaran, dimana siswa terlibat secara langsung dalam proses penemuan pemahaman materi yang diajarkan, sehingga siswa dapat lebih memahami materi yang diajarkan guru.

Penelitian ini dikuatkan oleh penelitian yang dilakukan sebelumnya oleh Martanti Dwi (2019) menyatakan bahwa model Problem Based Learning dapat meningkatkan keterampilan menulis teks eksposisi dimana rerata hasil belajar siswa mencapai nilai 80.2 dengan persentase ketercapaian 100\%. Sapta Wiguna (2020) 
menyatakan bahwa model Problem Based Learning dapat meningkatkan keterampilan menulis naskah pidato hal ini dibuktikan dengan adanya peningkatan dalam persentase ketuntasan pada setiap siklusnya, persentase ketuntasan pada tahap prasiklus hanya $66,25 \%$, pada siklus pertama terdapat peningkatan menjadi $72,5 \%$, dan pada siklus kedua mencapai $83,78 \%$ dan telah melebihi kriteria ketuntasan yang telah ditetapkan yaitu $75 \%$ dari 30 siswa.

\section{Sebagaimana}

dikemukakan pada uraian latar belakang masalah bahwa penelitian tentang penerapan problem based learning dalam meningkatkan keterampilan menulis yang teridentifikasi memiliki perbedaan dengan yang diteliti dalam penelitian ini. Penelitian yang teridentifikasi cenderung terkait keterampilan menulis laporan khususnya berdasarkan keterampilan menulis karangan eksposisi, dan kemampuan menulis teks eksposisi. Oleh karena itu penelitian yang dilakukan ini bertujuan untuk mengetahui apakah metode problem based learning dapat meningkatkan keterampilan menulis deskripsi siswa kelas IV SDN 3 Selajambe Kabupaten Kuningan. Berdasarkan uraian tersebut, peneliti tertarik untuk melakukan penelitian tentang peningkatan keterampilan menulis deskripsi melalui metode problem based learning di Kelas IV SDN 3 Selajambe Kabupaten Kuningan. Hasil penelitian diharapkan mampu memberikan kontribusi dalam meningkatkan mutu pendidikan dasar khususnya dalam meningkatkan kemampuan menulis deksriptif siswa Sekolah Dasar.

\section{METODE}

Dalam penelitian ini peneliti menggunakan metode penelitian tindakan kelas (classroom action research) dengan batasan kelas atau classroom action research yang mengacu pada model Kemmis dan McTaggart yang terdiri dari 4 komponen, yaitu : (1) perencanaan (planning), (2) tindakan (acting), (3) pengamatan (observating), (4) refleksi (reflecting), (Arikunto,2013).

Penelitian ini dilaksanakan untuk meningkatkan keterampilan menulis deskripsi melalui metode problem based learning. Subjek penelitian ini adalah siswa kelas IV SD Negeri 3 Selajambe yang berjumlah 25 siswa, 11 siswa laki-laki dan 14 orang siswa perempuan. Adapun instrument penelitian yang digunakan dalam penelitian ini adalah tes menulis karangan deskripsi yang dilakukan sebelum menggunakan metode problem based learning dan setelah menggunakan metode problem based learning. Tes dimaksudkan untuk mengetahui sejauh mana keterampilan siswa dalam menulis deskripsi. Teknik pengambilan data diperoleh dengan cara lembar pengamatan, tes dan dokumentasi. Teknik analisis data yang digunakan dalam penelitian ini ialah dengan menggunakan analisis data kualitatif dan analisis data kuantitatif. Analisis data yang digunakan dalam penelitian ini ialah data kualitatif model Miles and Hubreman, dimulai dengan mereduksi data, penyajian data sampai pada penarikan kesimpulan.

Data kuantitatif diperoleh dari tes menulis deskripsi yang metode problem based learning yang dinilai oleh observer melalui instrumen 
penilaian. Untuk melihat hasil tindakan digunakan studi proporsi nilai rata- rata sebelum dan sesudah mendapat tindakan. Untuk mengetahui kenaikan rata- rata pencapaian menulis deskripsi melalui pendekatan saintifik model problem based learning dibandingkan dengan skor target digunakan studi proporsi nilai rata- rata sebelum mendapat perlakuan. Maka untuk memudahkan dalam menginterpretasikan hasil,digunakan rumus sebagai berikut:

$$
\mathrm{N}=\frac{\text { Skor Yang Diperoleh }}{\text { Skor Maksimum }} \times 100
$$

\section{PEMBAHASAN}

Problem based learning merupakan salah satu proses pembelajaran yang dibentuk dalam suatu kelompok kecil dimana siswa diarahkan untuk dapat bekerja sama dalam proses pemecahan masalah yang tengah dihadapi, serta dalam mengoptimalkan keterlibatan dirinya dengan anggota kelompoknya. Dalam artian kegiatan pembelajaran yang dilakukan di dalam kelas dengan menggunakan metode problem based learning mengajak siswa untuk terlibat aktif dalam kelompok untuk pemecahan suatu permasalahan yang sedang dihadapi serta dapat memberikan solusi sebagai suatu cara dari pemecahan masalah tersebut. Dalam pembelajaran ini siswa harus lebih aktif dalam menerima materi yang diberikan oleh guru, begitu pula sebaliknya guru dapat lebih kreatif lagi dalam mengemas dan menyajikan materi yang diberikan kepada siswa guna menciptakan kondisi pembelajaran kondusif yang menimbulkan aktivitas pembelajaran siswa secara individu maupun secara berkelompok dapat menjadi bermakna. Selain itu dengan menggunakan metode problem based learning siswa dapat terlibat aktif dalam proses belajar mengajar sehingga siswa tidak hanya sebagai penerima materi saja tetapi siswa juga ikut terlibat dalam mengkonstruk pengetahuan yang mereka miliki sebagai suatu solusi dalam pemecahan masalah dengan cara mereka saling berdiskusi untuk menyampaikan apa yang mereka ketahui seperti dalam bagaimana memecahkan suatu masalah secara berkelompok.

Pada siklus I pelaksanaan pembelajaran menulis deskripsi melalui metode problem based learning menunjukan adanya peningkatan, dimana peningkatan tersebut terlihat dari skor yang diperoleh pada saat tes menulis deskripsi siklus I skor yang diperoleh paling banyak pada rentang nilai 69-75 hal ini membuktikan bahwa adanya penigkatan dalam menulis deskripsi, dimana peningkatan tersebut diikuti dengan perolehan nilai rata-rata meningkat menjadi 69,6. Akan tetapi penigkatan tersebut belum memenuhi kriteria ketuntasan yang diharapkan yaitu sebesar $75 \%$ siswa kelas IV yang memperoleh nilai 70. Dimana dari hasil tes menulis deskripsi pada siklus I hanya $60 \%$ siswa yang mencapai kriteria ketuntasan yang diharapkan atau sebanyak 15 siswa yang dinyatakan tuntas, sedangkan sebanyak $40 \%$ atau 10 siswa lainnya 
belum mencapai kriteria ketuntasan yang diharapkan.

Pada siklus II pelaksanaan pembelajaran menulis deskripsi melalui metode problem based learning menunjukan peningkatan yang signifikan, dimana peningkatan tersebut terlihat dari skor yang diperoleh pada saat tes menulis deskripsi siklus II skor yang diperoleh paling banyak pada rentang nilai 75-79 hal ini membuktikan bahwa terjadi penigkatan dalam menulis deskripsi yang dilaksanakn pada siklus II, dimana peningkatan tersebut diikuti dengan perolehan nilai rata-rata meningkat menjadi 75,6. Hal ini menandakan bahwa keterampilan siswa dalam menulis deskripsi mengalami peningkatan yang signifikan dan telah mencapai kriteria ketuntasan yang diharapkan yaitu sebesar $75 \%$ siswa yang memperoleh nilai 70 , meskipun pada tes menulis deskripsi pada siklus II ini terdapat 3 siswa yang belum mencapai kriteria ketuntasan akan tetapi tetap mengalami peningkatan pada setiap siklusnya.

\section{Gambar 1. Peningkatan menulis deskripsi}

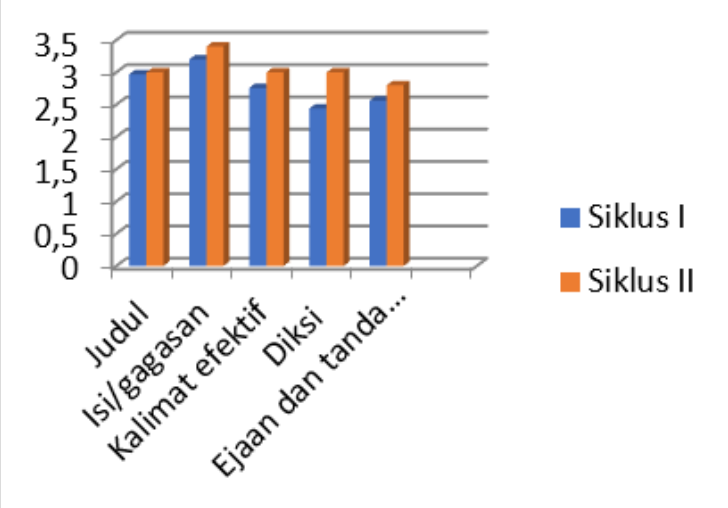

Berdasarkan hasil pengolahan data yang diperoleh dari hasil tes siklus I dan siklus II dapat disimpulkan bahwa peningkatan keterampilan menulis deskripsi dapat dicapai melalui pendekatan saintifik dengan metode problem based learning (pembelajaran berbasis masalah). Hal ini dapat dibuktikan dengan adanya peningkatan nilai keterampilan menulis deskripsi melalui instrumen tes yang berupa tes menulis deskripsi, yaitu 69,6 pada siklus I menjadi 75,6 pada siklus II. Sehingga dapat disimpulkan bahwa metode problem based learning dapat meningkatkan keterampilan menulis deskripsi di kelas IV SDN 3 Selajambe Kabupaten Kuningan.Dengan kata lain metode problem based learning dapat digunakan dalam pembelajaran Bahasa Indonesia khususnya dalam meningkatkan keterampilan menulis. 
Gambar 1. Grafik rata-rata tiap siklus

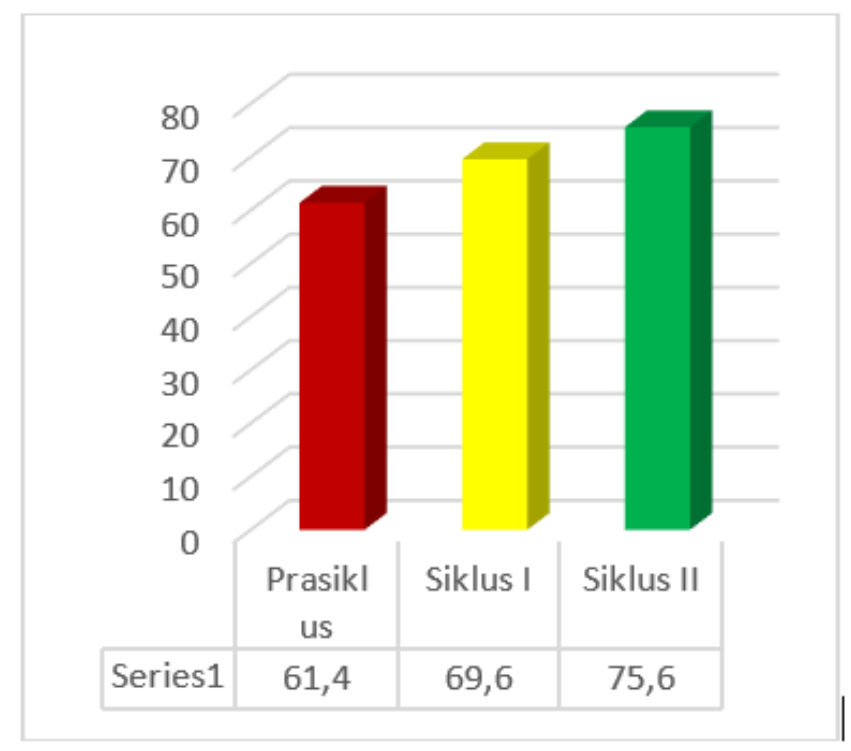

SIMPULAN

Berdasarkan hasil pembahasan yang telah di uraikan maka penulis menarik kesimpulan bahwa Penelitian yang dilaksanakan di SDN 3 Selajambe Kabupaten Kuningan mengenai strategi meningkatkan keterampilan menulis deskripsi melalui pendekatan saintifik dengan metode problem based learning. Berdasarkan hasil penelitian yang telah dilakukan, peneliti menyimpulkan bahwa :

a. Penggunaan metode problem based learning merupakan salah satu upaya dalam meningkatkan keterampilan menulis deskripsi, karena dengan metode yang mengarahkan siswa dalam masalah siswa dapat menggali sendiri informasi-informasi terkait bagaimana cara pemecahan masalahnya sehingga siswa dapat mengkonstruk sendiri informasiinsformasi terkait dalam proses pembelajaran.

b. Penggunaan metode problem based meningkatkan

keterampilan menulis deskripsi pada siswa kelas IV SDN 3 Selajambe kecamatan selajambe kabupaten kuningan. Hal ini dibuktikan dengan hasil analisis data terhadap keterampilan menulis deskripsi melauli metode problem based learning menunjukan tingkat keberhasilan siswa yang meningkat dari siklus I ke siklus II. Dari 25 jumlah siswa kelas IV di SDN 3 Selajambe kabupaten kuningan. Siswa yang mendapat 70 pada siklus I yaitu 15 siswa atau $60 \%$, sedangkan pada siklus II meningkat menjadi 22 siswa atau $88 \%$. Peningkatan dari siklus I ke siklus II cukup signifikan yaitu mencapai $28 \%$. Sedangkan target indikator ketercapaian yang diperoleh siswa minimal $75 \%$ dari seluruh jumlah siswa telah tercapai bahkan melebihi target yang diharapkan yaitu sebesar $88 \%$, maka keterampilan menulis 
deskripsi melalui metode problem based learning dapat ditingkatkan. Dengan kata lain strategi peningkatan keterampilan menulis deskripsi melalui metode problem based learning dikatakan berhasil atau tercapai.

\section{DAFTAR PUSTAKA}

Abidin, Yunus.(2012). Pembelajaran Bahasa Berbasis Pendidikan Karakter. Bandung :Refika Aditama.

Arikunto, Suharsimi.(2013). Prosedur penelitian suatu pendekatan praktik. Jakarta : Rineka Cipta

Atmaningsih.Dyah, Wijayanti.Aprilia, Ardiyanto.Asep,(2019)." Keefekt ifan Model Pembelajaran PBL Media Audio Visual Terhadap hasil Belajar IPA Kelas III SDN Baturagung," Mimbar PGSD Undiksha,Vol.7 (2)

Dalman, H. 2016. Keterampilan Menulis. Jakarta : RajaGrafindo Persada.

Juldianty.(2016)."Peningkatan

Keterampilan Menulis Narasi Melalui Penggunaan Media Gambar Seri Pada Siswa Kelas III ," Jurnal Pendidikan Dasar, Vol.7 (2):390.

Karim, A., Faiz, A., Parhan, M., Gumelar, A., Kurniawaty, I., Gunawan, I., ... Suanah, A. (2020). Managerial leadership in green living pharmacy activities for the development of students ' environmental care in elementary schools. Journal of Critical Reviews, 7(13), 714-719.

Kristyanawati. Martanti Dwi, Suwandi. Sarwiji,Rohmadi.Muhammad.(2 019)." Peningkatan Keterampilan Menulis Teks Eksposisi Menggunakan Model Problem Based Learning," Scholaria : Jurnal Pendidikan dan Kebudayaan, Vol.9 (2)
Kusrianti.Anik, Suharto,Teguh.V, (2019)."Penerapan Model Pembelajaran Problem Based Learning Dengan Multimedia untuk Meningkatkan Kemampuan Menulis Puisi Siswa ," Linguista : Jurnal IImiah Bahasa, Sastra ,Vol.3 (2):147

Lestari Anna, Wahyudi, Chrysti.S, Kartika.(2016)."Penerapan Pendekatan Saintifik Dengan Media Konkret Dalam Peningkatan Berpikir Kritis Pembelajaran IPA Tentang Cahaya Pada Siswa Kelas V $S D^{\prime \prime}, \quad$ Jurnal Kalam Cendekia,Vol.4,(3.1):529.

MS. Zulela,(2017)."Keterampilan Menulis Narasi Melalui Pendekatan Konstruktivisme di Sekolah Dasar", Jurnal Pendidikan Dasar, Vol 8 (2):113. Nurdin, Syarifuddin. H. Dan Adriantoni.(2016). Kurikulum dan Pembelajaran. Jakarta : RajaGrafindo Persada.

Qodriah, S. L., Hartati, W., \& Karim, A. (2019). Self-leadership and career success: Motivation of college lecturers. Journal of Leadership in Organizations, 1(2), 79-95.

Rusman.(2015). Pemebelajaran

Tematik Terpadu. Jakarta: Raja Grafindo Persada.

Saleh, Zulela.H.M. (2013). Terampil Menulis di Sekolah Dasar. Tangerang : Pustaka Mandiri.

Semi, Atar.M. (2007). Dasar- dasar Keterampilan Menulis Bandung : Angkasa. 
Suari,Ni Putu.(2018)." Penerapan Model Pembelajaran Problem Based learning untuk Meningkatkan Motivasi Belajar IPA" Jurnal IImiah Sekolah Dasar, Vol.2 (3)

Wahyuni, Sri.(2015). "Pembelajaran Menulis Teks Eksposisi Dengan Model Pembelajaran Berbasis Masalah di SMP". Jurnal
Penelitian Pendidikan INSANI, Vol.18 (1).

Wiguna. Sapta, Rasyid. Yumna, Purbarini.

Asti,(2020)."Peningkatan

Keterampilan Menulis Naskah Pidato melalui Model Problem Based Leraning," Jurnal Pendidikan Bahasa dan Sastra Indonesia, Vol.5 (1) 